\title{
Condutas sem crença e obras de arte sem espectador
}

\author{
Paul Veyne \\ Collège de France
}

A realidade, segundo dizem, é mais forte do que todas as descriçôes que dela podemos fazer. E é preciso admitir que a atrocidade, quando vivida, ultrapassa todas as ideias que dela podemos ter. Entretanto, quando se trata de valores e de crenças, acontece o contrário: a realidade é muito inferior às representaçôes que fornece de si mesma e aos ideais que professa. Chama-se mediocridade cotidiana essa perda de energia. Madame Bovary costumava crer que em Nápoles a felicidade era tão fortemente enraizada quanto os laranjais, e que tinha a densidade de uma pedra. A sabedoria das naçóes, por sua vez, diz que não é nada disso. "O paraíso é desejado, porém o mais tarde possível", afirma um provérbio cristão. Essa cotidianidade impóe um problema, ou toda uma série de problemas (a obra de Georg Simmel poderia ser considerada desse ângulo), a não ser que ela seja feita de todos os nossos erros, espontâneos ou científicos, sobre o homem e a sociedade. Não sei onde li (ou talvez tenha sonhado) a história de um jovem etnógrafo que partiu para estudar uma tribo que, segundo se dizia, acreditava que o mundo sucumbiria se os sacerdotes deixassem que o fogo sagrado se extinguisse. O etnógrafo supunha que esses sacerdotes se sentissem muito ansiosos, como se tivessem nas máos o detonador de uma bomba atômica. Autorizado a dar uma olhadela no templo do fogo, observou alguns eclesiásticos tranquilos que cumpriam uma tarefa de rotina. A realidade é raramente enfática. Diz-se que os ritos e os costumes, por exemplo, traduzem as crenças de uma sociedade; as imagens pintadas ou esculpidas fazem ver aquilo que uma sociedade crê ou servem para fazer crer o que essa sociedade vê; as esculturas das catedrais eram a bíblia dos iletrados. É certo? Constata-se que, na maioria das vezes, as pessoas participam dos ritos sem acreditar em suas significaçôes e, em todo caso, sem se interessar por elas ${ }^{1}$, porque a liturgia não é um meio de comunicação que veicula informaçôes. Constata-se também que as pessoas não olham para as imagens (quantos parisienses olharam para os baixos-relevos napoleônicos da coluna Vendôme?) e que, se tentaram fazê-lo, não souberam decifrar a sua iconografia, nem mesmo vê-las: localizadas muito alto, no topo dos edifícios, as imagens são quase sempre indecifráveis. Seria preciso, então, esboçar uma sociologia da arte em que a obra de arte, longe de veicular uma iconografia e uma ideologia, fosse um cenário para o qual nem mesmo se olhasse, que mal se visse, e que, contudo,

\footnotetext{
${ }^{*}$ Conduites sans croyances et oeuvres d'art sans spectateurs. Diogène, n. 143, jul./set. 1988, p. 3-22. Esta tradução foi feita pelo Ateliê de traduçóes do Laboratório de pesquisa em história das práticas letradas (PEHL), coordenado por Andrea Daher, com a participação de Clara Carvalho, Gabriel Vertulli, Gabriela Theophilo, Henrique Gusmáo, Karla de Aquino, Isabelle Weber, Iuri Bauler, Monique Ferreira, Raquel Campos e Renata Rufino; a revisão técnica e a edição final do texto são da coordenadora.

${ }^{1}$ BATESON, G. Naven. A Survey of the Problems suggested by a Composite Picture of the Culture of a New Guinea Tribe drawn from Three Points of View. Stanford: Stanford University Press, 1936 (tradução francesa: La cérémonie du Naven. Paris: Éditions de Minuit, 1971). Capítulo IX: "Às vezes ignora-se quase que por completo a significação ritual das cerimônias, e a ênfase recai exclusivamente sobre sua funçáo como meio de celebrar algo. Dessa forma, no dia em que se celebrava uma cerimônia relativa à fertilidade e à prosperidade, e quando um novo piso havia sido instalado na casa cerimonial, a maioria de meus informantes me disse celebrar essa cerimônia 'por causa do novo piso'. Raros eram os homens que tinham consciência plena do significado ritual da cerimônia, ou tinham por ele algum interesse; e mesmo estes interessavam-se não tanto pelos efeitos mágicos da cerimônia, mas sim pelas suas origens totêmicas, o que é altamente importante para os clãs cujo orgulho nobiliário repousa largamente sobre o caráter particular de sua genealogia totêmica”.
} 
fosse muito importante. $\mathrm{O}$ estudo de todas as mediocridades seria um vasto programa. Limitemo-nos aqui à mediocridade da arte.

Em Roma, não muito longe do antigo Fórum, eleva-se a trinta metros de altura a coluna de Trajano, cujo eixo é envolvido, numa espiral de 23 voltas, por um friso esculpido em que 184 cenas e milhares de figuras contam, como numa "história em quadrinhos", a conquista de Dácia por Trajano. À exceção das duas primeiras espirais, esses relevos são indiscerníveis para os espectadores. Os arqueólogos os estudam através de binóculos. Além do mais, ninguém teria vontade de pormenorizar essa profusáo de elementos repetitivos, nem poderia seguir esse relatório de campanhas militares pontuadas pela conquista de aldeias bárbaras ${ }^{2}$, cujo nome e posição num mapa eram totalmente desconhecidos. Os historiadores creem conseguir explicar a coluna de Trajano dizendo se tratar de uma obra de "propaganda imperial", o que mostra o quanto uma racionalidade um tanto limitada, que não sabe nem mesmo distinguir expressão e informação, tem prestígio, ainda hoje, ao dizer algo à "sociedade" ou ao enunciar o que esse algo supostamente "traz à sociedade". Pode-se, contudo, duvidar que os romanos do tempo de Trajano tenham olhado muito mais para esses relevos, materialmente náo visíveis, do que os romanos de hoje, e duvidar também que tenham se lançado num espetáculo, em que acabam por desrespeitar suas próprias consciências, dando 23 voltas em torno da coluna, com o nariz para cima. A coluna náo informa os humanos, ela os faz apenas ver que proclama a grandeza de Trajano, diante do tempo e do céu. Da mesma forma, no topo do rochedo de Bisutin, Dario, o Grande, mandou gravar uma grande inscrição trilíngue à glória de seu reinado. Essa inscriçáo náo foi feita para ser lida: foi colocada no topo de um penhasco e somente as águias ou os alpinistas pendurados por cordas teriam podido lê-la.

A coluna exprime a glória de Trajano, da mesma forma que o céu (que é inútil detalhar estrela por estrela) exprime a glória de Iahweh. Em ambos os casos, é preciso haver estrelas e cenas esculpidas em demasia: a expressão de uma superioridade só é indubitável se for transbordante. Para explicar a coluna, a história da arte não deveria se contentar em estudar o detalhe da composição das diferentes cenas, sua iconografia, o relato contínuo, a perspectiva em voo de pássaro, as relaçóes com o realismo idealizado dos frisos helenísticos etc. Deveria constatar, sobretudo, que a coluna é, essencialmente, um duplo recorde quantitativo, pelo número de metros quadrados de baixos-relevos e pela altura da construção. A coluna é um tipo de "arquitetura de obelisco", tão apreciada em Roma quanto em Londres ou em Paris, no século XIX. Ela era tão alta quanto os edifícios mais elevados de Roma. O Coliseu, é bem verdade, tem 48 metros, ou seja, dez a mais. Mas, entre os obeliscos, ele é como o cipreste em relação às outras árvores que crescem em largura: o traço retilíneo do cipreste, fino como uma vela, dá mais impressão de verticalidade e de altitude que as outras árvores. Quanto ao friso esculpido, seu papel é meramente decorativo, embora seja figurado e narrativo. O melhor uso que se pode fazer de construçóes desse gênero não é a descrição em detalhe de sua decoração, mas é subir nelas. A iconologia, segundo Panofsky, tem aqui pouca utilidade. Em Paris, a coluna Vendôme e a coluna de Julho fazem parte de um mesmo tipo de arquitetura de vertigem. No século XIX, a visita e a escalada dessas duas construçóes eram atividades de programas turísticos e de casamentos populares (assim como em L’assommoir, de Zola). "Se estivesses no topo da coluna Vendôme, ousarias lançar-te pelos ares?”, diz um herói de La peau de chagrin. Não sabemos se a escada interior da coluna de Trajano era acessível ao povo romano, mas náo importa: a coluna exprime a grandeza vertiginosa do imperador.

\footnotetext{
${ }^{2}$ No plano "geográfico" dos frisos da coluna, ver BOBU-FLORESCU, F. Die Trajansäulle. Bucarest: Akademie-Verlag, 1969. p. 52-56; GAUER, Werner. Untersuchungen zur Trajanssäule. Darstellungsprogramm und künstlerischer Entwurf. Berlin: Mann, 1977. p. 14, que afirma que as imagens dessas aldeias não são representaçôes fiéis ou pitorescas, mas imagens convencionais.
} 
"Um preconceito" - escreveu Robert Klein ${ }^{3}$ — "nos faz crer que a causa de uma obra de arte estivesse naquilo que ela tinha a dizer"; daí o sucesso da iconologia. O momento da recepção da obra pelos espectadores foi apenas recentemente levado em consideração. Pouquíssimos arqueólogos pensaram em se interrogar sobre o curioso problema da não visibilidade dos baixos-relevos da coluna de Trajano, $\mathrm{e}$ aqueles que o fizeram ${ }^{4}$ manifestaram algum embaraço. Lehmann-Hartleben constata o fato e o atribui à má coordenação entre o mestre da obra e o chefe da equipe de escultores. Richard Brilliant vê aí um fracasso artístico, mas reconhece, por outro lado, que o importante era que o espectador "grasped all at once wherever the view stood". Bianchi Bandinelli vê uma consequência da liberdade do artista, que encontra satisfaçáo ao criar, mesmo se os frutos de seu trabalho não sejam nada visíveis. Werner Gauer, por sua vez, observou que o friso, enrolado em espiral, também tem correspondências verticais com voltas sobrepostas, de modo que a obra deve também ser lida do alto. Um artigo publicado em 1981 na revista Prospettiva acreditou ter resolvido o problema da não visibilidade: os relevos teriam sido destinados a serem vistos do alto do terraço dos edifícios que cercavam a coluna. $\mathrm{O}$ autor do artigo acrescenta que a explicação de Bianchi Bandinelli manifesta um idealismo burguês... A ideia de uma visão a meia altura nem sequer merece discussão (permanecendo no solo ou se colocando mais acima, apenas uma ou duas espirais são nitidamente legíveis, e, além disso, seria preciso também girar em torno da coluna): mas tudo isso é a demonstração do embaraço em que são postos os historiadores da Antiguidade pela não visibilidade. Ou talvez eles nem sonhem com a não visibilidade, ou quem sabe vejam nela um acidente, ou ainda uma aparente estranheza que deveria ser submetida à regra.

Ora, existe em Paris uma obra, a coluna Vendôme, imitação napoleônica muito fiel à coluna de Trajano ${ }^{5}$, que apresenta a mesma não visibilidade. Simplesmente, como se trata de uma obra moderna, os historiadores olham-na com um olho menos erudito e menos embaraçado. Admitem a náo visibilidade tão pacificamente que, logo após sua construção, o escultor Ambroise Tardieu publicou num in-fólio a gravura dos relevos (A Coluna do Grande Exército, gravada por Tardieu) e explicou em sua "Advertência" que, uma vez que os relevos não são visíveis, pensou, com isso, prestar uma contribuição. As pessoas que olham as 23 espirais da coluna Vendôme não distinguem grande coisa (mas sentem que se elas estivessem mais bem posicionadas, distinguiriam, o que é algo importante, como veremos). Reconhecem confusamente cenas militares, os chapéus dos marechais e, aqui e ali, o legendário chapeuzinho do ditador da Córsega. Podem também ler a coluna verticalmente: em qualquer ponto em que nos situemos, se olharmos de baixo para cima, poderemos sempre avistar, numa determinada altura, o célebre chapeuzinho, visível de todos os lados.

Portanto, basta, para trazer à tona uma evidência, que estejamos diante de uma obra que não pertença a uma civilização passada ou estrangeira. É uma aplicação inesperada da parábola evangélica da palha e da viga. Cada civilizaçáo se considera natural, e nenhuma se surpreende consigo mesma. Os problemas, ou sua ocultação, começam com o outro. Ou melhor, uma vez que ultrapassamos uma fronteira espacial ou temporal, mudamos de critério. Entre nós, aplicamos uma grade social, por exemplo, e, quando estamos no estrangeiro, uma grade nacional: o que um francês perceberá na França como

${ }^{3}$ KLEIN, R. La forme et l'intelligible. Paris: Gallimard, 1970. p. 234 (tradução brasileira: A forma e o inteligivel. São Paulo: Edusp, 1998).

${ }^{4}$ Citemos LEHMANN-HARTLEBEN. Die Trajanssaule: ein romisches Kunstwerk zu Beginn der Spatantike. Berlim/ Leipzig: W. de Gruyter \& Co., 1926. v. I, p. 1; BRILLIANT, R. Roman art from the Republic to Constantine. Londres: Phaidon 1974. p. 192; BANDINELLI, B. Dall'ellenismo al medioevo. Roma: Editori Riuniti, 1978. p. 123; La Colonna Traiana, o della libertà dell'artista. In: GAUER, Werner. Untersuchungen zur Trajanssäule, op. cit. p. 45; Prospettiva, n. 26, p. 2, jul. 1981 (com detalhes interessantes na nota 11 sobre a policromia desses relevos, o que completa as afirmaçóes de BECATTI, G. La colona Traiana, espressione somma del rilievo storico romano. Aufstieg und Niedergang der römischen Welt, II, 12, n. 1, p. 550, 1972).

${ }^{5}$ Salvatore Settis estudou brilhantemente a imitação dos relevos trajanos pelos escultores de Napoleão. 
um defeito pequeno-burguês lhe soará, na América, como um defeito americano, imputável a toda a América enquanto tal. Daí decorre também a ilusão dos "bons velhos tempos" e da laudatio temporis acti: lemos o presente através do fait divers e o passado através da norma. Se alguns relevos modernos não são visíveis, é porque é normal que possa ser assim: não somos problema para nós mesmos. Ao menos nesse sentido, temos a vantagem de não levantar o problema falsamente, como fizemos no caso da coluna de Trajano.

A má visibilidade das obras de arte é um fato normal, tamanha sua frequência. Para sabê-lo, basta vagar pela basílica de Sáo Pedro, em Roma, e elevar o olhar para as abóbadas, a cúpula ou o topo do baldaquino de Bernini. Efeitos decorativos e racionalidade museográfica sáo duas coisas diferentes. Em Santa Maria Maior, os mosaicos da nave formam pequenos quadros de pouco mais de um metro, dispostos a muitos metros de altura. Neles, não se distingue nada, muitas vezes náo se pode sequer contar o número de personagens e, para estudar seu conteúdo, é preciso consultar as reproduçóes na publicação de Wilpert. Ademais, o espectador médio era incapaz de saber o que representava grande parte das cenas bíblicas: à não visibilidade visual vem se somar a obscuridade da iconografia. Mas, como diz Peter Brown, ${ }^{6}$ e daí? Numa determinada cena que representa a bênção de Jacó por Isaac, o espectador via, principalmente, as colinas verdes e os ciprestes, uma imagem paradisíaca, menos mística que idílica: a cristandade antiga representava as alegrias do paraíso tão sensivelmente quanto, mais ou menos no mesmo período, o mundo muçulmano.

Podemos ver os detalhes com dificuldade, não chegar a compreendê-los e mal olhá-los. Basta que o espectador, a partir do chão onde se encontra, veja o suficiente para ter certeza de que eles, mesmo que não estejam ao seu alcance, poderiam, entretanto, ser vistos detalhadamente, caso ele estivesse mais bem posicionado. Ou seja, basta ter certeza de que os detalhes não foram negligenciados, que o artista não poupou esforço, nem o comanditário poupou dinheiro. A racionalidade da expressão ("Que grandeza a minha, ó céus!") não é a da informação ou da propaganda (“Saibam que sou grande”). Uma expressão calculada em excesso, que visa a maior exatidão possível, perde seu efeito: a verdadeira grandeza não deve poupar, mas resultar em superabundância. Deve-se, portanto, distinguir uma arte para a qual se olha, segundo Gombrich", de uma arte em que não se presta atenção, que se chama "decorativa”. Não se podia nunca esperar que o friso do Pártenon fosse decifrado: ele deveria receber apenas olhares de passagem, de soslaio. Como afirma Leroi-Gourhan: ${ }^{8}$ "O critério da decoração está mais na intenção que lhe é dada do que nos próprios elementos: num santuário, os grandes afrescos edificantes são elementos de decoração, simples guirlandas de folhagens".

Certamente. Mas será esta, de fato, uma arte que se olha? Não seria melhor falar em espectadores que olham a arte e não se contentam com uma visão lateral e global? Existem, de fato, indivíduos que chamamos connaisseurs, amadores, e que olham. Eles existem até mesmo entre os "primitivos", que, segundo o testemunho de alguns etnógrafos, são tão capazes quanto nós de julgar se a música tocada naquele ano na festa tribal era mais bela que a do ano anterior. Ao mesmo tempo, esses mesmos "primitivos" julgam que essa bela música é a própria voz de seus ancestrais, e ouvem-na com uma emoção religiosa9 ${ }^{9}$. Trata-se, portanto, menos de espécies de indivíduos diferentes do que de atitudes diferentes diante das obras. É enganoso afirmar, assim, que antigamente as estátuas gregas eram ídolos e que são obras de arte apenas para nós: elas já eram obras de arte para os gregos. Eram também, ao menos, uma

${ }^{6}$ BROWN, P. Society and the holy in Late Antiquity. Berkeley; Los Angeles: University of California Press, 1982. p. 205 (tradução francesa: La société et le sacré dans l'antiquité tardive. Paris: Seuil, 1985. p. 154).

${ }^{7}$ GOMBRICH, E. H. The sense of order. Oxford: Phaidon, 1979. p. 116.

${ }^{8}$ LEROI-GOURHAN, A. Le geste et la parole. Paris: Albin Michel, 1965. p. 143.

${ }^{9}$ FELD, S. Sound and sentiment. Birds, weeping, poetics, and song in Kaluli expression. Filadélfia: University of Pennsylvania Press, 1982, livro que conheci graças a Jean Molino. 
terceira coisa: representaçóes e retratos do que acontecia no mundo divino e do aspecto das divindades. Informavam sobre o mundo das alturas, assim como a televisão nos permite ver o mundo político e seus atores. Enfim, sua beleza decorativa exprimia também a potência e a piedade do devoto que as havia construído ou do clérigo do santuário.

Pluralidade de atitudes, muitas vezes de um só e mesmo espectador, pluralidade correlativa das funçôes da arte: cada obra tem a sua, ou as suas. Para estudar a coluna de Trajano como obra de arte, dizer o que a caracteriza e a distingue, é preciso, antes de se perder nos detalhes, se perguntar se o friso era destinado a fornecer uma ilustraçáo informativa (à maneira das pinturas que relatavam um combate de gladiadores que tivesse se tornado famoso ${ }^{10}$ ); se era uma obra para o deleite ou uma simples decoraçáo triunfal, uma acumulação de fatos de guerra, seguramente apropriada, embora um tanto automática. Quanto ao estudo detalhado do friso, ele não trará grande coisa para a caracterização da própria coluna. Em contrapartida, será instrutivo para outros capítulos da história da arte romana (tradição iconográfica dos ateliês, história da narração contínua etc.), o que será benéfico para a eventual caracterização de outras obras. Da mesma forma, quando um mosaico antigo representa uma lenda mitológica pouco conhecida e razoavelmente esotérica, a iconografia da lenda oferece informaçóes preciosas sobre a difusão da erudição mitológica, ao menos no interior do mundo dos ateliês ou de seus cadernos de modelos. Contudo, a caracterização do próprio mosaico propóe problemas bem diferentes: o comprador (diferentemente do artista) tinha preocupaçóes eruditas e sabia o que o mosaico representava? Pode ser que tenha visto nele apenas uma bela imagem, ou menos ainda: uma decoração que trará mais valor para sua estima social porque custa caro. Um comprador florentino exigiu de Ghirlandajo, a quem encomendou um afresco, que "fornecesse informaçôes" precisas sobre a vida de Batista, seu santo padroeiro (tema de um trabalho célebre de Aby Warburg). Resta saber o que fez Ghirlandajo e o que o mais comum dos florentinos via nisso: talvez uma decoração devota que não era para ser detalhada. No século XVII, em contrapartida, um connaisseur que comprasse um Le Nain sem dúvida não o fazia porque a nobreza de toga tinha conservado laços no campo, como supunha um tanto pesadamente Anthony Blunt: ${ }^{11}$ talvez, antes, ele admirasse a beleza da pintura, da arte pela arte, ou sonhasse devota e poeticamente perante a diversidade das condiçóes que Deus ofereceu aos homens, perante o formidável desvio do destino de diversos filhos do Todo-Poderoso, que aí mostra o seu mistério e a sua glória. Um quadro pode muito bem ter toda uma iconografia, porém uma iconografia náo é algo que se compre, ou pelo menos nem sempre.

O próprio artista pinta ou esculpe por amor à iconografia, ou, mais frequentemente talvez, não lhe dá grande importância. Em geral, o artista trabalha para um espectador ideal, análogo ao "leitor ideal" de que a semiologia atual merecidamente ergue o fantasma no horizonte de cada obra literária. No tempo de Fídias, as estátuas dos frontóes gregos foram finamente bem acabadas, tanto do lado não visível, que ficava apoiado no tímpano, quanto do lado visível. $\mathrm{O}$ escultor quis satisfazer o espectador ideal (que vê tudo com os olhos do espírito) e, em primeiro lugar, a si mesmo, que tem o ideal do trabalho bem-feito. Talvez também tenha querido satisfazer os deuses, que amam os trabalhadores escrupulosos. Quando este espectador ideal — que geralmente é o duplo do artista — se encarna, leva o nome de "connaisseur", o homem que desposa o ponto de vista do criador e que pode compreender suas intençốes. ${ }^{12}$

O que nos leva abusivamente a crer que a iconografia seja o mais importante é o fato de que ela é o elemento mais visível, e com razão: as imagens são uma descrição, e não uma linguagem. Como diz

\footnotetext{
${ }^{10}$ Os testemunhos antigos atestam que essas pinturas de combate eram observadas em detalhe e avidamente.

${ }^{11}$ BLUNT, A. Art and architecture in France, 1500 a 1700. Melbourne: Penguin Books, 1953. p. 157 (que acrescenta, é verdade: "mas isso é pura especulação").

${ }^{12}$ GOMBRICH, E. H. Meditations on a hobby horse: and other essays on the theory of art. Londres; Nova York: Phaidon, 2001 (1963). p. 74.
} 
Jean-Claude Passeron, a imagem não é uma linguagem porque ela não pode dizer "sim”, "não", "quase”, "talvez", "amanhã" e porque, se por um lado ela comporta convençóes, por outro não é codificada (as únicas imagens verdadeiramente codificadas são os mapas geográficos modernos). Entretanto, se for o caso de mostrar como é feita uma máquina complicada ou o paraíso terrestre, as imagens são insubstituíveis. Seu poder descritivo as torna muito apropriadas para fazer ver, ou então para fornecer informações no sentido preciso do termo (as imagens não têm shifters). Suponhamos que a decoração esculpida ou pintada nas igrejas tenha sempre sido visível, que tenha sido compreensível para a média dos espectadores e que eles tenham se preocupado em olhá-la: mesmo nesse caso, a igreja não foi o "catecismo dos iletrados" que se diz; sua imagética serviu ao prazer, mais que à instrução. Ela desempenhou o papel que desempenha hoje em dia a fotografia de reportagem, que agrada os leitores lhes fazendo ver "como foi" a coroação da rainha, ao lado do artigo do repórter que fornece as informações sobre a coroação. Tal é a origem, ou uma das origens, das artes naturalistas na Grécia ou na Itália gótica.

As imagens não podem existir sem descrever, sem dizer "como foi". Simplesmente não nos interessamos sempre em saber "como foi". É exatamente por isso, com exceção da fotografia de reportagem, que não examinamos espontaneamente as imagens: mal as olhamos, a não ser que sejamos um connaisseur, um vice-criador. Na maior parte das vezes, prestamos uma atenção distraída, lateral, nas imagens, como define Gianni Vattimo. ${ }^{13}$ Exceto se a imagem procura um efeito de choque, como fazem os cartazes publicitários. Caso contrário, tudo se limitará ao sentimento da presença de uma imagem ("Olhe, é decorado", "Olhe, é bonito", "Olhe, é um quadro e não um pôster, então custa caro") e à classificação sumária dessa imagem ("É um quadro de igreja”, "É uma mulher nua”, "É arte abstrata para esnobes”14). Atitudes variáveis historicamente ("É tão bem pintado que poderia ser confundido com o modelo"), mas igualmente medíocres. Portanto, não há que se superestimar, à primeira vista, a importância da arte na mentalidade de uma época. A história, ou pelo menos a história geral, deve lembrar que as obras de arte funcionam apenas a dez por cento da sua capacidade... Mais uma vez, remetemo-nos a Peter Brown. ${ }^{15}$

Então, seria fraca a importância da arte na história? Não tão rápido. São as funçôes intensas e as atitudes fortes que desempenham um papel muito reduzido. Mesmo se considerarmos a mais fraca das atitudes (atenção global e distraída) e a mais fraca das funçôes (decoração, quadro da vida), nada pode se igualar à importância que os homens atribuíram à arte ao longo de sua história, nem mesmo a religiáo. Sabemos que quase todo o excedente das sociedades antigas foi aplicado em edifícios, colunas e estátuas, de tal modo era violenta a necessidade de expressão. Digamos de passagem, a declaração de que existe toda uma escala de graus de intensidade na arte, longe de nos tiranizar, deveria nos deixar à vontade: um conservador de museu talvez não seja obrigado a obedecer aos sociólogos e a se comportar em função do menor desses graus, o da história do gosto e dos modos...

A arte que importa, apesar de sua fraca intensidade ou graças a ela, é a que compóe o quadro da vida, o cenário urbano, e ninguém presta atenção no cenário desse teatro da comédia social. A toda e qualquer interpretação sociologizante que faz da arte uma ideologia, é legítimo retorquir: "Quem nunca observou as esculturas da coluna Vendôme? Que habitante de Marselha nunca olhou os relevos da porta de Aix, de David d'Angers?” (relevos esses, aliás, melhores que a maior parte dos famosíssimos "relevos históricos” da Roma antiga). Essa indiferença não contradiz a destinação desses monumentos erguidos perante o tempo, mais do que perante os homens. Os monumentos náo são mensagens ao outro, nem mesmo a expressão ideal da bela humanidade e, menos ainda, a face da sociedade. Falam para expressar

\footnotetext{
${ }^{13}$ VATTIMO, G. La fine della modernità (tradução francesa: La fin de la modernité: nihilisme et herméneutique dans la culture post-moderne. Paris: Éditions du Seuil, 1987. p. 89-91).

${ }^{14}$ Cf. MOULIN, R. Le marché de la peinture en France. Paris: Éditions de Minuit, 1967. p. 70 e 409 ss.

${ }^{15}$ BROWN, P. Society and the holy in Late Antiquity, op. cit. p. 202 (tradução francesa, p. 151).
} 
a potência que os fez emergir, como os autores de panfletos políticos e grafiteiros militantes que escrevem menos para se dirigir aos leitores do que para expressar aquilo que transborda em seus coraçóes e manifestar sua existência.

O hall de uma universidade, cujas paredes estão cobertas de grafites políticos que ninguém se preocupa em decifrar, para seus frequentadores tem o mérito de não ser frio como o hall de um banco e de fazê-los viver nesse pequeno mundo, tal como o concebem. Ninguém tampouco observava detalhadamente a coluna de Trajano. Acontece que, simplesmente pelo fato de vê-la, cada um sentia que o espaço estava ocupado por uma alta potência de linguagem transbordante, que não era ouvida, mas que passava, como o vento, bem alto, acima das cabeças, proferindo um discurso de que só se entendia o sentido geral. Pois os discursos confusos ou as frases pomposas são direito e, ao mesmo tempo, signo dos deuses, dos oráculos e dos mestres. O que o monumento comporta, em suma, de ideologia, é o próprio direito que se arroga de existir, do mesmo modo que, num país submetido a um regime autoritário, os alto-falantes que difundem nas ruas os discursos oficiais importam mais por sua onipresença do que por aquilo que repetem. A coluna de Trajano é, de certa maneira, propaganda, porém, justamente, não por sua imagética, e sim por sua presença e pela potência que sua redundância exprime.

O mesmo poderia ser dito das produçóes da natureza, da physis. A arte prova a existência de uma força social, comparável à força que levanta montanhas e que, com a minúcia do cinzel, nelas esculpe pequenas flores, que não formam um alfabeto a ser soletrado. Nesse sentido, a expressão é comunicação não intencional: ela é indício de sua autoria, e não poderia deixar de sê-lo, mesmo que se recusasse. Uma vez, um arquiteto, discípulo de Mies van der Rohe, foi incumbido de construir um banco. Seus gostos estéticos e suas convicçóes políticas impediam-no, evidentemente, de tratar um banco como um templo do capitalismo e nele projetar colunas, estátuas e frontôes. Ele ergueu um arranha-céu nu, austero, sem o menor traço de ideologia. Infelizmente, esse edifício provou, entáo, até que ponto o capitalismo ousava ser transparente, seguro de si e dominador, desdenhoso em relação à necessidade de se justificar e de se embelezar. Com seu gosto pela nudez funcional, o arquiteto tinha tornado aquele grande banco autoevidente, self-evident, e seu prédio impressionava os que passavam diante dele.

A arte faz parte das condutas que não têm objetivo, télos, ${ }^{16}$ condutas que não se compreendem por sua finalidade e que não se medem por seu resultado. Não é um meio de comunicação, porque não é, de modo algum, um meio. Ela se explica por sua origem, se exprime por se exprimir, como o fogo que queima por queimar e que cessa, não quando atinge um resultado, mas quando esgota sua energia. A expressão por si só não pode tampouco medir os seus efeitos, pode apenas esgotar-se. Daí a importância quantitativa da arte na história, repleta de expressóes, ao mesmo tempo desinteressantes e eficazes, pirâmides, capitais, cerimoniais e panfletos. E todos são sensíveis à força que nelas se expressa, ou até mesmo ao sentido que elas implicam.

Em resumo, onde seria tentador buscar uma essência da arte ou uma atitude fundamental ("uma estátua de uma deusa era um ídolo, agora é uma obra de arte”) percebemos uma multiplicidade de funçôes e uma distribuição social das atitudes correspondentes. Uma confusão, uma bruma de cotidianidade, toma o lugar das grandes superfícies de cor intensa. Falta pensar a atitude do personagem que é o mais intenso de todos: o próprio artista, ao qual foram encomendados os baixos-relevos para a coluna de Trajano ou as estátuas de bronze que foram colocadas acima da escadaria lateral do Grand Palais em Paris, a 25 metros do chão. O artista hesita entre o ideal de seu ofício - como meio de expressão, um meio de se livrar do brilho interior que o consome, um meio de dizer o que ele é diante do céu - e o gosto de se comunicar com o outro e de convencê-lo, o gosto do testemunho e da mensagem, como se dizia em meados do século XX, com uma ingenuidade devota. Ele hesita entre o gosto da solidáo e da

${ }^{16}$ Cf. HADOT, P. Comment la multiplicité des idées s'est établie et sur le bien. Introduction à Plotin, Traité 38. Paris: Éditions du Cerf, 1988. p. 69. 
vocação, de um lado, e o do sucesso, do outro. Se o primeiro triunfar (como é de se esperar) — como o gosto pelo "espectador ideal" que plana no ar, a 25 metros do cháo, que triunfa sobre o gosto dos espectadores reais —, então o artista deverá modelar suas estátuas tão cuidadosamente quanto se devessem ser vistas bem de perto, com uma lupa; chegará até mesmo a cinzelar suas pupilas, como se poderá verificar ao se sobrevoar o Grand Palais de helicóptero, um século depois da fundição dessas estátuas.

Pluralidade de funçóes de uma mesma obra, multiplicidade de atitudes segundo os indivíduos: isso é verdade para obras de arte, mas não menos para costumes, rituais, mitos, cerimoniais, de tal modo que a questáo de saber o sentido de um mito ou de uma cerimônia revela-se muito sumária.

$\mathrm{Na}$ primeira nota deste artigo, foi citado um texto de Bateson em que se pode ler o seguinte: na Nova Guiné ou na Papua, em uma aldeia às margens do rio Sepik, muito conhecido pelos colecionadores de arte oceânica, uma cerimônia acontece. Nossos historiadores das religióes, que se preocupariam com a significaçáo dessa liturgia, veriam nela uma cerimônia destinada a promover a fertilidade do solo. Numa história das religióes oceânicas, a cerimônia seria descrita, portanto, num capítulo relativo aos rituais de fertilidade. Seus participantes, que são, não obstante, os principais interessados, não veem nada disso, mas somente uma solenidade que celebra a ocasiáo pela qual é executada, ou seja, a da inauguração de um edifício público. Enfim, um grupo de virtuoses ou de esnobes procura se interessar, não por essa ocasião banal e nem mesmo pelo texto esotérico da cerimônia, mas por um terceiro elemento: acontece que, com a finalidade de melhor promover a fecundidade, o ritual comemora, ocasionalmente, determinados ancestrais míticos dos clãs. Esses esnobes, que descendem desses clãs, ignoram a fertilidade e se mostram alheios à inauguração do edifício para se dedicarem à comemoração dos velhos nomes nobres. Qual é, portanto, a "verdadeira” função da cerimônia? Seria possível ainda ousar fazer dela uma espécie bem catalogada, um "ritual de fertilidade", como nos tempos de James Frazer? Na França, $A$ marselhesa, hino guerreiro, serve para enobrecer a inauguração de creches. À sua maneira, os papuas não fazem nada de diferente. Sua estranheza se esmigalha, portanto, e se torna medíocre.

Podemos reafirmar, sobre os ritos e os cerimoniais, o que dizíamos sobre as obras de arte: sua multiplicidade de significaçóes e a fraca intensidade da significação, mais geralmente aceita, fazem com que os cerimoniais sejam condutas que funcionam apenas a dez por cento de sua energia; e a significação geralmente aceita não é aquela que seu conteúdo implica ou a que seu criador desejava: não é a letra de $A$ marselhesa o que importa, quando, ao som da música, se inaugura a creche mencionada. Entre os papuas, há teólogos, mitógrafos que elaboraram esses rituais de fecundidade que servem para inaugurar uma construção pública. Em sua maior parte, os cerimoniais são condutas que não têm por função afirmar a crença que veiculam. Neste momento, os católicos franceses consideram, de modo geral, que a reforma litúrgica de sua Igreja foi mal concebida. Se isso for verdade, o erro consistiu, talvez, em ter tomado um cerimonial por uma proclamação de fé, por conta de um excesso de intelectualismo. A analogia entre obras de arte e cerimoniais tem fundamento: as cerimônias são arte, como um quadro ou um poema; os desfiles militares também, assim como a complicação gratuita de regras de etiqueta à mesa, no Ocidente. E dir-se-ia o mesmo dos mitos, essa literatura oral de divertimento. Há sociedades, muitas vezes ditas "primitivas", em que a criação ritual tem uma importância tão grande quanto, em outras, a criação musical ou plástica; a cerimônia é a arte principal dessas sociedades. A liturgia é toda uma arte: uma arte não é um meio de comunicação, de propaganda ou de instrução, mas uma celebração. A missa dita em latim não é uma coisa mais absurda do que a não visibilidade dos relevos da coluna de Trajano.

A pluralidade das funçóes de um mesmo costume conduz a um erro frequente: julgamos nossos próprios costumes a partir de uma de suas funçóes e os costumes estrangeiros a partir de outra. O cos- 
tume estrangeiro reveste-se, assim, de uma falsa originalidade. Afirma-se que nossos Jogos Olímpicos são, antes de tudo, um espetáculo, ao passo que o concurso olímpico da Antiguidade teria sido uma cerimônia religiosa, ou que a luta japonesa (sumô) era outrora um verdadeiro rito. Nos Holzwege, Heidegger sustenta que "ninguém ia a Olímpia dizendo para si mesmo que era algo a ser visto uma vez na vida". Segundo ele, os gregos aderiam sem reserva à sua vida coletiva e religiosa - o que ele considera muito bom. Mas, felizmente, ele se engana: os gregos iam a Olímpia exatamente como se vai a um espetáculo, apaixonavam-se pela competição e pelos vencedores e não atribuíam mais importância ao aspecto religioso do concurso do que nós mesmos atribuímos à cerimônia da tocha olímpica que abre nossos jogos. Do mesmo modo, Martin Nilsson, que muito conhecia sobre o assunto, praticamente se dispensou de falar de Olímpia em sua história da religião grega. Não devemos ceder, aqui, à lenda das origens mais puras, nem pretender que uma significação ritual original foi apagada ao longo dos anos: ela se apagou desde o início, desde Homero, que descreve os jogos fúnebres em honra a Pátroclo como um espetáculo menos fúnebre que esportivo.

A diferença entre a Antiguidade e nós — pois essa diferença existe, entretanto — não se situa aí. Primeiro, nas sociedades antigas, um costume que não servisse para nada e que fosse mais que um divertimento era, por isso mesmo, dedicado aos deuses, para que tivesse uma finalidade em si mesmo e para tirar do prazer a sua futilidade agressiva. Quanto a nós, preferimos legitimar essa futilidade fazendo com que os prazeres estejam sob a alçada de um ministério dos lazeres ou do tempo livre. Segundo, a religiáo era também, na Antiguidade, um meio de estabelecer as obrigaçóes. Celebrava-se o concurso olímpico uma vez a cada quatro anos numa determinada data porque era ritual, costumeira, sagrada, ao passo que nós o celebramos numa data fixa porque é necessário estar de acordo para se decidir a data e, uma vez fixada, cumpri-la. Da mesma forma, nas nossas estradas, os carros trafegam de um lado direito ou esquerdo, conforme determina o código nacional — , pois é preciso escolher um mesmo lado, enquanto na Antiguidade se teria trafegado na faixa da direita porque a da esquerda seria considerada nefasta e de mau agouro.

Um rito (ou cerimonial) é uma obra, instantânea ou elaborada ao longo de séculos, individual ou coletiva, que não traduz o que pensava uma sociedade: ela não é sua fisionomia, porém exprime o que seu criador sabia e pensava. Logo, evitemos inferir, por exemplo, a partir do cerimonial de coroação dos reis, o que era a monarquia e o que se pensava dela, e com isso evitaremos contribuir com a análise ideológica dos símbolos, um tanto automática. Esse cerimonial não nos faz ver a própria face da monarquia: é somente um retrato seu, feito por um pintor da corte. Os súditos do rei, muito provavelmente, pensavam outra coisa do regime monárquico. E, mais provavelmente ainda, pensavam muito menos que isso: todo retratista embeleza, interpreta e torna precisos os traços do modelo.

Sendo a função de um rito celebrar, solenizar, e não simbolizar e informar, é quase impossível inferir, a partir de um costume ritual, a crença a que corresponde. Os ritos funerários da Antiguidade romana são cada vez mais conhecidos, graças às escavaçóes, sem que nossos conhecimentos sobre as crenças funerárias tenham aumentado. $\mathrm{O}$ que pensar do fato de que se depositava, muitas vezes, um pouco de comida junto ao morto? Que os contemporâneos de Cícero e de Marco Aurélio acreditavam que a tumba era uma casa onde o defunto continuava a viver e a se alimentar? Para termos clareza sobre isso, passemos dos antigos romanos aos chineses de hoje ou de ontem.

Há um século e meio, o padre Huc escrevia: ${ }^{17}$ "Os chineses têm o hábito de oferecer pratos aos mortos e, algumas vezes, refeiçôes esplêndidas, que lhes eram servidas diante do caixão, entre a família, ou diante do túmulo, depois do sepultamento. O que pensavam os chineses sobre essa prática? Muitas pessoas acreditaram e escreveram que, em sua opiniáo, as almas dos defuntos gostavam de vir satisfazer-

${ }^{17}$ HUC, R. P. Souvenirs d'un voyage dans la Tartarie, le Thibet et la Chine. Paris: Édition d'Ardenne de Tizac, 1925. v. IV, p. 135. 
-se com as partes mais sutis e delicadas, digamos, dos pratos que lhes eram oferecidos. Parece-nos que os chineses não são tão desprovidos de inteligência a ponto de levarem adiante uma tolice dessas. Um dia, perguntamos a um mandarim amigo nosso, que acabara de oferecer uma suntuosa refeição diante do caixão de um de seus confrades defuntos, se ele compartilhava da opinião de que os mortos tinham necessidade de alimento como tal. 'Como podeis supor que eu tenha um pensamento como esse?', respondeu-me espantado. 'Quem seria tão insensato a ponto de acreditar que os mortos precisam comer? Minha inteligência seria assim táo limitada a ponto de não ver que isso seria uma loucura? Pretendemos honrar a memória de nossos parentes e de nossos amigos, dando-lhes o testemunho de que estão sempre vivos na nossa lembrança e de que gostamos ainda de servi-los, como se eles existissem"'. O mandarim, é bem verdade, acrescentou a comprovação de que o problema da crença não é simples: "Entre o povo contam-se muitas fábulas, mas quem não sabe que as pessoas grosseiras e ignorantes são sempre crédulas?” Talvez. Porém, por mais grosseiras que possam ser, elas encarnam um problema: que grau de realidade tinha a crença das pessoas grosseiras na sobrevivência dos mortos e em sua necessidade de alimentação?

Além da pluralidade de atitudes, além da multiplicidade de funçôes, um terceiro aspecto do esmigalhamento da cotidianidade aparece: a diversidade dos modos de crença (a crença na imortalidade da alma, por mais firme que seja, não mudou em nada, por exemplo, a ideia que os homens fazem da morte). Radcliffe-Brown relata: ${ }^{18}$ "Um morador de Queensland encontrou um chinês que segurava uma tigela de arroz cozido sobre a tumba de seu irmáo. $\mathrm{O}$ australiano, brincando, lhe perguntou se ele pensava que seu irmão vinha comê-la. O chinês respondeu: 'Não. Oferecemos arroz aos mortos para expressar nossa amizade e nossa afeição. Mas, tendo em vista a sua pergunta, suponho que, na Austrália, vocês coloquem flores sobre o túmulo de um morto porque creem que ele gostará de olhá-las e de sentir o seu perfume"”.

Talvez esse chinês tenha um único defeito: ser filho de seu século e de seu meio e ser também tão racionalista quanto o australiano que o interrogou. Nesse século, a opinião esclarecida na China era a mesma que na Europa. Depois da China vista pelos ocidentais, eis o Ocidente visto pela China: em 1898, quando da tentativa de reforma dos Cem Dias contra a imperatriz Tseu Hi (Cixi), um alto mandarim modernista publicou um escrito reformador em que se lia o seguinte: "Embora os Europeus não façam oferendas ou sacrifícios sobre os túmulos, eles têm, entretanto, a prática de visitá-los; o ato de colocar flores sobre os túmulos é considerado pelos Europeus uma marca de respeito para com os mortos que ali estão enterrados. Dessa forma, portanto, os Europeus realmente respeitam a relaçáo que deve existir, piedosamente, entre o pai e o filho" ${ }^{19}$.

Tal era a opiniáo dos espíritos avançados. Por que eles se recusam a acreditar que os defuntos continuam a viver em seus túmulos? Porque essa ideia do além lhes parece contestada pela evidência do cadáver. Isso é esquecer que existem várias maneiras de crer, várias modalidades de crença e que, em certo estado de mentalidade, nenhuma censura — nem social, nem interna - impede de acreditar sinceramente em concepçôes consolatórias: não se crê da mesma maneira no paraíso e nos cadáveres, mesmo que a crença em ambos tenha a mesma intensidade.

Uma mesma conduta (colocar sobre o túmulo um pouco de comida ou objetos domésticos à disposição do defunto) será, segundo a sociedade ou o grupo social considerado, um cerimonial de ho-

\footnotetext{
${ }^{18}$ RADCLIFF-BROWN, A. R. Structure et fonction dans la société primitive. Paris: Éditions de Minuit, 1972. p. 232.

${ }^{19}$ Ver a obra do vice-rei do Hou-Koang, TCHANG TCHE T’ONG. K'ien-hio P'ien [Exhortation à l'étude... ouvrage traduit du chinois par Jérome Tobar, S. J.] Xangai: Imprimerie de la Presse Orientale, 1898. p. 5. Sobre as crenças funerárias dos ocidentais, na mesma época, ver LINTON, R. De l’homme. Paris: Éditions de Minuit, 1968. p. 391 : “O protestante americano médio, por volta do começo do século XIX, podia se sentir profundamente abalado por um sermão sobre o Juízo Final, dizer que seus parentes amados o esperam no Céu e sentir um medo profundo dos cemitérios com o cair da noite”.
} 
menagem desprovido de qualquer crença; ou um gesto de consolo a que os atores, sem acreditar verdadeiramente, se entregam como atores que representam num teatro; ou, enfim, será uma verdadeira crença, mas que não abole por isso outras crenças que aparentemente a contradizem. No sul da Itália, terra cristã por excelência, um etnógrafo recolheu, há uns cinquenta anos, o seguinte lamento recitado por uma esposa: "E agora devo dizer-te, tu que fostes o tesouro de tua mulher, o que pus no teu caixão: duas camisas, uma nova e outra refeita, a toalha para que te laves o rosto no outro mundo, e também teu cachimbo, pois tinhas tanta paixáo pelo tabaco! E agora, como fazer para enviar-te doravante os charutos no outro mundo??. ${ }^{20}$ Estamos diante de um tipo de teatralização em que os vivos fingem acreditar numa ficção e até o tabaco e os charutos entram no jogo.

A teatralização funerária é algo muito comum e resulta numa verdadeira crença. Fala-se frequentemente do caráter trágico que teria "a alma etrusca", do colorido sombrio das "crenças funerárias" da Etrúria antiga, com seus assustadores demônios e demônias do inferno. Esquece-se táo logo que essa demonologia é, sobretudo, o produto de um excesso de invenção expressionista por parte dos talhadores etruscos que esculpiam os túmulos. Quase se poderia ousar dizer que os etruscos jogavam com o medo produzido por meio dessa imagética funerária, tal como, em determinados períodos, os americanos produzem medo com seus próprios filmes. Mas sabe-se também que, com isso, acaba-se por provocar medo, realmente, e por se acreditar na demonologia infernal. A variedade, a complexidade e a riqueza das cerimônias funerárias através do mundo deixam supor que os túmulos foram o lugar eleito nesse processo de crença pela teatralizaçáo. Todavia, determinadas sociedades são hostis a toda e qualquer forma de teatralização, por um tipo de puritanismo.

A realidade de uma crença não se mede nem por sua não contradição, nem pelas aplicaçóes práticas que dela são feitas: a fé que não age é, muitas vezes, uma fé sincera. É possível se acreditar numa sobrevida dos defuntos no túmulo, mesmo constatando com os próprios olhos que eles não são nada além de poeira. É possível acreditar que continuam a se alimentar, sem tirar consequências materiais dessa crença (não se renova a comida sobre o túmulo, ela é depositada uma única vez, no dia do funeral). $\mathrm{O}$ que desestabiliza uma crença não é o choque da realidade, mas uma censura social ou pessoal. Com efeito, uma espécie de sentido interno nos permite distinguir as diferentes modalidades de nossas crenças, do mesmo modo que sentimos, a cada momento, a postura de nossos membros. As modalidades consolatórias (ou cerimoniais) de crença são, assim, marcadas por um indício que as caracteriza e que as crenças desencantadas, por exemplo, náo têm. Esse sentimento interno do modo de crença nos permite, em último caso, controlar e censurar nossos pensamentos, da mesma maneira que controlamos o estilo de nossos discursos (pode-se assim, por preocupação de elegância ou por modéstia, reagir contra uma inclinaçáo para falar enfaticamente e para multiplicar prosopopeias e metonímias: eliminam-se essas figuras de retórica, sem que jamais, talvez, se tenha aprendido o que é uma metonímia). Ora, acontece que, em determinadas sociedades, entre as quais a nossa, uma censura recai sobre as crenças consolatórias, do mesmo modo como poderia recair sobre as posturas descontraídas ou sobre as falas enfáticas. Não crer para se consolar é um imperativo de dignidade intelectual. Crer que os mortos se alimentam dos pratos depositados ao lado deles deixa de ser, entáo, verdadeira crença, para passar a ser uma simples conduta de homenagem a que nenhuma crença responde mais.

Pergunta-se: é psicologicamente possível crer, ao mesmo tempo, que o corpo de um defunto está em decomposição e que esse mesmo corpo continue a receber alimento? Deve-se responder que é total-

${ }^{20}$ Lamento recolhido na Lucânia e publicado por DE MARTINO, E. Rapporto etnografico sul lamento funebre lucano. Società, X, n. 4, p. 655-665, 1954. 
mente possível. A máquina de viajar no tempo me ensinou. Ouvi, com efeito, o poeta René Char, num desses dias em que estava entregue a seu onirismo mítico pessoal, explicar que as grandes ideias são depositadas nas praias pela maré e que são descobertas no fundo das poças d'água formadas durante a vazante, à beira-mar. Ele mesmo havia descoberto isso durante um passeio pela praia de Varengeville, convidado por Georges Braque. Esse mito significa que as grandes ideias são postas às margens da nossa consciência pelo vaivém dos pequenos acontecimentos que o Eterno Retorno balança no oceano que é o cosmos, e que as descobrimos nas poças de reflexáo que se formam em nossas meditaçóes cotidianas. Char não dizia (e não pensava) que as reflexôes eram semelhantes às poças d'água. Pensava, com efeito, nas poças d'água reais (ao menos quando se entregava ao sonho acordado, o que, como poeta, fazia muitas vezes). Entretanto, não tinha cavado com as próprias mãos, na praia de Varengeville, os buracos em questão. O pensamento simbólico e mítico funciona sempre assim. Por exemplo, o fundador do maniqueísmo pensava que os elementos do cosmos eram purificados e elevados graças aos recipientes de uma nória cósmica, cujas três rodas eram o ar, a água e o fogo. Ele não dizia e não pensava que o processo de purificação era análogo a uma nória: pensava que era uma nória. Todavia, quando elevava os olhos ao céu, não esperava ver essa nória (e não se decepcionava por não a ver). O pensamento simbólico e mítico está de acordo consigo mesmo: conhece suas próprias contradições e evita o máximo chocar-se com elas.

Teatralização, programas míticos de verdade, semicrenças, pluralidade de funções e de atitudes, todo esse esmigalhamento se explica: criações culturais, crenças, artes, itinerários turísticos consagrados são tipos de instituições, de "espíritos objetivos". São grandes coisas que existem em si mesmas, que cada um se esforça para integrar e que ninguém vive plenamente. Decerto, cada hora da vida cotidiana comporta uma gota de religiosidade que se desconhece ou de prazer estético que se ignora. Porém, entre essa experiência individual e uma religião ou uma ópera há um abismo ${ }^{21}$. A felicidade em Nápoles, sonhada por Madame Bovary, não podia existir como cotidianidade, mas apenas como espírito objetivo, tal como as listas turísticas de lugares a serem visitados e, neles, de sentimentos a serem experimentados.

Quando a beleza ou o divino se tornaram uma arte ou uma religiáo, a vida cotidiana passou a não mais estar na mesma escala que esses espíritos objetivos: Bayreuth deixou de estar na mesma proporção de algumas horas de prazer estético de uma centena de indivíduos. Produz-se então uma "relação de objeto", object relationship, um "investimento", tal como os capitais individuais serão investidos em pessoas morais chamadas sociedades anônimas. Quanto ao prazer estético, tornou-se admiração e amor, localizado fora, no seu objeto: deixou de ser uma inquietação íntima para tornar-se o fato de uma sinfonia mostrar-se radiante. Os sacrifícios que os indivíduos devotos ou estetas fazem aos seus espíritos objetivos não são, de forma alguma, pagos através de benefícios cotidianos (a religião ocupa apenas uma hora ou duas do dia do mais devoto dos homens), mas por meio da importância atribuída ao objeto. Nunca um indivíduo se torna, ele mesmo, espírito objetivo. De Hölderlin a Heidegger, o sonho de uma antiga Grécia ideal é apenas uma quimera, que prova o quanto Heidegger era um espírito nebuloso.

O retorno às origens é, portanto, vão: as origens são bastante cotidianas. A religiosidade das origens, preferível à nossa secularização bárbara, existe apenas na nostalgia dos filósofos edificantes. Longe de estar crivada dos esquecimentos de uma autenticidade primeira, a história é feita de lutas contra a cotidianidade, de esforços educativos ou, mais ainda, para dizer as coisas como elas são, de adestramentos no sentido do melhor ou do pior, Bayreuth ou Verdun. Que uma sociedade se assemelhe ao seu ideal quando a Grécia é tida por esteta ou a Idade Média por uma cristandade — não significa um retorno a uma autenticidade, mas o efeito de um adestramento difícil e sempre imperfeito. Um exército não é a

${ }^{21}$ SIMMEL, G. Philosophische Kultur. Berlim: Karl Wagenbach, 1983. p. 37. 
mesma coisa que uma reunião de homens situados, cada um deles, diante da necessidade de se defender: nossa biblioteca tem mais livros do que poderíamos ler, e guarda muitos que jamais reabriremos.

É o que George Simmel chamava de "a tragédia da cultura" 22 , que não era entendida como um drama doloroso, mas como uma leve e incessante defasagem entre a cotidianidade e os espíritos objetivos. Essa defasagem é inspiradora de quimeras para uns - que tomam os espíritos objetivos de antigamente pela cotidianidade das origens - , e suscita em outros um ódio da cultura. Por amor pela transparência e pela coincidência consigo mesmo, Rousseau odiava as ciências e as artes; por decepção amorosa, Ruskin odiava toda cultura que não pudesse ser possuída por seus amantes; René Char considera que "as civilizaçôes são gorduras" e que seria preciso "esfregar o gordo", pois, muitas vezes, os indivíduos com forte vida interior odeiam os espíritos objetivos que forçam a alma a sair de si mesma ${ }^{23}$. Sêneca achava que a posse de uma biblioteca era contra a natureza.

Os valores são postos, na maioria das vezes, fora do indivíduo: vivemos ou morremos por eles, não os vivemos, não os sentimos, os professamos mais do que acreditamos neles. O verso que Apollinaire escrevia em 1918, "No coração do soldado palpita a França", é convencional e falso: nada de parecido palpita no próprio coração. "Queria pintar o cinza”, dizia o Flaubert de Madame Bovary. Há um trágico medíocre e cotidiano que não nasce dos conflitos entre valores, mas das incoerências da realidade consigo mesma. Pois o mundo não é "mal feito": ele não é nada feito.

$\mathrm{O}$ verdadeiro drama de Madame Bovary é este: ela não podia se tornar espírito objetivo. Se tivesse podido, teria encontrado nele a sua realização. Seu tormento é o mesmo de Flaubert em pessoa: como encontrar uma realização da existência na própria existência? ${ }^{24}$ Está claro que uma biblioteca que se lesse a si mesma, uma obra de arte que fosse sua própria espectadora ou uma conduta que acreditasse, ela própria, no que faz seriam seres completos. E mesmo seres divinos, uma vez que, neles, o conhecido se conheceria a si mesmo e, como diziam os gregos, a inteligência e os inteligíveis seriam a mesma coisa. Mas, como não o são, isso nos soa na alma como um vazio perene. Por mais que um poeta tenha o sentimento de ter criado em seu poema um ser imputrescível, resta-lhe o sofrimento de saber que a inteligência de seu poema depende de cada leitor. O poema seria divino se ele se lesse a si mesmo. É cotidiano o que não é divino, ou seja, todo o resto.

Para resumir a diferença entre a simples experiência vivida e os espíritos objetivos, três exemplos bastam. O primeiro será a sensibilidade em relação à paisagem. Não se trata, justamente, de uma "evolução

\footnotetext{
${ }^{22}$ SIMMEL, G. Philosophische Kultur, op. cit. p. 195-218 (tradução francesa de Cornille-Ivernel: La tragédie de la culture. Paris: Éditions Rivages, 1988. p. 177-216). A réplica de Ernest Cassirer (Zur Logik der Kulturwissenschaften. Darmstadt: Wissenschaftliche Buchgesellschaft, 1961. capítulo 5) desconhece o pensamento de Simmel, que não deplora que o espírito objetivo bloqueie a espontaneidade individual, mas, ao contrário, que o indivíduo não chegue jamais a assimilar suas criaçóes objetivas. O pluralismo trágico de Simmel é incompatível, de fato, com nossa tendência natural para a conciliação e o otimismo. Simmel acredita na pluralidade inconciliável dos valores e na discórdia interna do próprio indivíduo (Einleitung in die Moralwissenschaft. Aalen: Scientia Verlag, 1983. v. 2, p. 360-426), assim como no equívoco entre o instinto e as aspiraçóes mais elevadas - realidade perturbada que, na falta de melhor expressão, chama "vida" (seu Fragment über die Liebe é característico, nesse sentido; ver SIMMEL, G. Das Individuum und die Freiheit. Berlim: Wagenbach, 1984. p. 19-28). Estamos aqui longe de Bergson, o que por vezes foi dito. O que Simmel chama "vida" é o caráter misto de toda e qualquer realidade, em que essências, funçóes ou ordens se misturam ou se contrariam. O amor não é nem essência una, nem agregado de pulsão e de ideal, porém misto não conceitualizável: "eine unlösbare Aufgabe” (p. 25). Sobre o indivíduo que não chega a assimilar todo o espírito objetivo (e, por exemplo, a aproveitar plenamente a instituição dos museus), cf. Das Individuum und die Freiheit, op. cit. p. 90 ss.

${ }^{23}$ CHAR, R. Oeuvres complètes. Paris: Bibliothèque de la Pléiade, 1983. p. 466 e 55; SIMMEL, G. Das Individuum und die Freiheit, op. cit. p. 87; idem. Philosophische Kultur, op. cit. p. 203.

${ }^{24}$ SIMMEL, G. Pilosophische Kultur, op. cit. p. 150.
} 
da sensibilidade", mas de uma mudança de categoria. No tempo de Molière, vive-se a paisagem: "O campo, esse mês, não está muito florido”, diz um herói de Tartufo. A partir de Chateaubriand, a sensibilidade em relação à paisagem tornou-se toda uma arte, com seu vocabulário e com a obrigação de sentir o que deve ser sentido. Consequência: a dificuldade de assegurar a difusão popular das artes é porque não basta deixá-las à disposição do povo; é preciso, principalmente, dar-lhe o sentimento de que é nobre fazer o esforço de se iniciar nesse espírito objetivo que é a arte. Pois a cultura, assim como o esporte, é um prazer que exige um esforço. Enfim, falávamos da contradição entre a realidade do cadáver e a crença na sobrevivência dos mortos que é preciso alimentar no túmulo: a contradição pode ser vivida sem dificuldade, pela simples razão de que a experiência do cadáver é uma "experiência", enquanto a crença no além é algo bem mais elaborado, ou seja, um espírito objetivo. Ora, como os espíritos objetivos estão sempre distantes, só se adere às crenças pela metade, por dever, e rindo delas, quando for o caso. 